\title{
Respiratory activity and pigment metabolism in fresh-cut beet roots treated with citric acid
}

\author{
Ricardo A Kluge ${ }^{1}$; Maria Carolina D Vitti ${ }^{1}$; Fabiana F Sasaki ${ }^{1}$; Angelo P Jacomino ${ }^{2}$; Celso L Moretti ${ }^{3}$ \\ ${ }^{1}$ USP-ESALQ, Depto. Ciências Biológicas, C. Postal 9, 13418-900 Piracicaba-SP; ${ }^{2}$ USP-ESALQ, Depto. Produção Vegetal; ${ }^{3}$ Embrapa \\ Hortaliças, C. Postal 218, 70359-970 Brasília-DF; rakluge@esalq.usp.br; mcdvitti@gmail.com; fsasaki@esalq.usp.br; \\ jacomino@esalq.usp.br; moretti@cnph.embrapa.br
}

\begin{abstract}
Beet roots cv. Early Wonder were graded for firmness, color and size, and were peeled inside a cold room $\left(10^{\circ} \mathrm{C}\right)$. Roots were then shredded (2 mm thick), sanitized for 6 minutes $\left(\mathrm{NaClO} / 200 \mathrm{mg} \mathrm{L}^{-1}\right)$, rinsed and centrifuged. Fresh-cut beet roots were then treated for 5 minutes with citric acid in the following concentrations: 0 (control), $500 ; 1,000 ; 1,500$ and $2,000 \mathrm{mg} \mathrm{L}^{-1}$. The material was centrifuged again, placed in trays, wrapped with PVC plastic film, and stored at $5^{\circ} \mathrm{C}$ and $85-90 \%$ HR for 10 days. Every two days, treatments were analyzed for respiratory activity and betacyanin and betaxanthin contents. The application of citric acid caused the reduction of respiratory rate in the fresh-cut tissue. In the second day of storage, control showed the highest respiratory activity among treatments, reaching around $77 \mathrm{~mL} \mathrm{CO} \mathrm{kg}^{-1} \mathrm{~h}^{-1}$. Citric acid solution dips in a concentration higher than $500 \mathrm{mg} \mathrm{L}^{-1}$ contributed to a decrease in respiratory activity and no peak in $\mathrm{CO}_{2}$ evolution was observed. There were significant differences among all treatments during the storage period for the contents of betacyanin, which were around 40;45; 48;

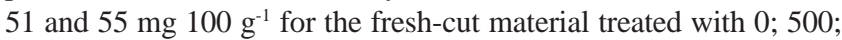
1,$000 ; 1,500$ and $2,000 \mathrm{mg} \mathrm{L}^{-1}$ of citric acid, respectively. Also, levels

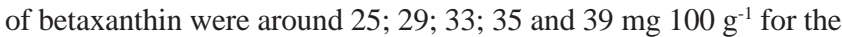
material treated with $0 ; 500 ; 1,000 ; 1,500$ and $2,000 \mathrm{mg} \mathrm{L}^{-1}$ of citric acid, respectively. The application of citric acid after minimal processing apparently have the ability to reduce respiratory rate and the degradation of pigments, which contributes to extend the shelf life of the fresh-cut product.
\end{abstract}

Keywords: Beta vulgaris L., respiration, betacyanin, betaxanthin, minimal processing.

\section{RESUMO}

Atividade respiratória e metabolismo dos pigmentos de beterrabas minimamente processadas tratadas com ácido cítrico

Beterrabas 'Early Wonder' foram selecionadas quanto à firmeza, cor e tamanho e descascadas em câmara fria $\left(10^{\circ} \mathrm{C}\right)$. As raízes foram cortadas ( $2 \mathrm{~mm}$ de espessura), sanitizadas, enxaguadas e centrifugadas. As beterrabas foram tratadas com ácido cítrico nas concentrações: 0 (controle), 500; 1000; 1500 e $2000 \mathrm{mg} \mathrm{L}^{-1}$. O produto foi novamente centrifugado, colocado em bandejas envoltas com filme de PVC e armazenado a $5^{\circ} \mathrm{C}$ e $85-90 \%$ de umidade relativa durante 10 dias. A cada dois dias, foram avaliados a atividade respiratória e os teores de betacianina e betaxantina nos tratamentos. A aplicação de ácido cítrico nas diferentes concentrações reduziu a taxa respiratória nos tecidos minimamente processados. No segundo dia de armazenamento, o tratamento controle apresentou a maior atividade respiratória alcançando valores próximos a $77 \mathrm{~mL}$ $\mathrm{CO}_{2} \mathrm{~kg}^{-1} \mathrm{~h}^{-1}$. A aplicação de ácido cítrico igual ou maior a $500 \mathrm{mg} \mathrm{L} \mathrm{L}^{-1}$ contribuiu para o decréscimo da atividade respiratória e o pico na evolução de $\mathrm{CO}_{2}$ não foi observado. Foi verificada diferença significativa entre os tratamentos durante todo o armazenamento para os teores de betacianina, tendo sido observados valores ao redor de 40;

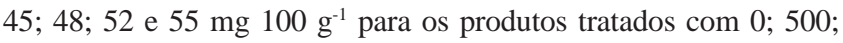
$1.000 ; 1.500$ e $2.000 \mathrm{mg} \mathrm{L}^{-1}$, respectivamente. Os níveis de betaxantina para beterrabas minimamente processadas foram ao re-

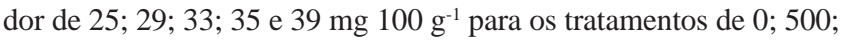
$1.000 ; 1.500$ e $2.000 \mathrm{mg} \mathrm{L}^{-1}$, respectivamente. A aplicação de ácido cítrico é sugerida durante o processamento mínimo como forma de reduzir a taxa respiratória e a degradação de pigmentos, contribuindo assim para o aumento da vida de prateleira de produtos minimamente processados.

Palavras-chave: Beta vulgaris L., betalaína, betacianina, betaxantina, processamento mínimo.

(Recebido para publicação em 27 de março de 2008; aceito em 31 de outubro de 2008) (Received in March 27, 2008; accepted in October 31, 2008)

$\mathrm{D}$ uring the past few years fresh-cut products have grown rapidly both in the foodservice sector and at the retail level. Focusing consumer convenience, they are prepared and handled aiming at offer a fresh and healthy product (Moretti \& Sargent, 2002). The obtaining of freshcut products involves many steps such as cleaning, washing, trimming, coring, slicing, shredding, and other related operations (Cantwell, 2000).
Fresh-cut business is an activity showing exponential increase in many countries, especially in large metropolitan areas, such as São Paulo, one of the biggest cities in Brazil, where supermarkets sell around US\$ 4 million of fresh-cut products monthly, considering both fruits (54\%) and vegetables (46\%) (Rojo \& Saabor, 2002).

In general, fresh-cut products have a short shelf life, which is mainly due to the mechanical stresses. In the cut surface, cells and membranes are damaged leading to alterations in the whole tissue metabolism. Many authors have observed increasing in carbon dioxide and ethylene evolution (Brecht, 1995; Moretti et al., 2000, 2002a), water loss (Moretti \& Sargent, 2000), alterations in flavor and aroma (Moretti et al., 2002b), decline in levels of nutrients such as ascorbate (Gil et al., 2006), development of off-odors 
(Beaulieu, 2006), and increase in the activity of enzymes related to enzymatic browning, e.g., phenylalanine-ammonialyase (PAL), polyphenol oxidase (PPO) and peroxidase (POD) (Degl'Innocenti et al., 2005). Kato-Noguchi \& Watada (1997) observed that respiratory activity of freshcut carrots was drastic reduced by the addition of citric acid, which is related to the inhibition of phosphofrutokinase, which catalyzes the phosphorilation of fructose 6phosphate into fructose 1,6-bisphosphate, in the glycolitic pathway of the respiratory metabolism.

Among many fruit and vegetable crops that are being processed in Brazil, beet roots are increasing in importance. They are pink-reddish in color due to the presence of a group of pigments named betalain, which was misdesignated as anthocyanin due to the presence of nitrogen in their molecule. These pigments were soluble in water and are divided in two groups: betacyanin (related with the red color) and betaxanthin (related with the yellow color). These two groups of pigments are present in beet roots and are involved with the characteristic color of this vegetable crop (Fenema, 1995).

One of the main technological problems found by processors dealing with fresh-cut beet roots is the significant discoloration and dehydration of the minimally processed material. Washing and rinsing operations carried out after slicing have favored the loss of betacyanin and betaxanthin, since these pigments are soluble in water (Nilson, 1970).

The factors mentioned above, the economical importance of this vegetable crop, as well as the lack of information in the consulted literature regarding the study of fresh-cut beet roots focusing pigments degradation, the present work was carried out aiming to study the effects of citric acid in the respiratory activity and in the content of betalain in fresh-cut beet roots.

\section{MATERIAL AND METHODS}

Beet roots cv. Early Wonder were obtained from a local grower in Piracicaba, São Paulo State, Brazil, and taken to the postharvest laboratory.

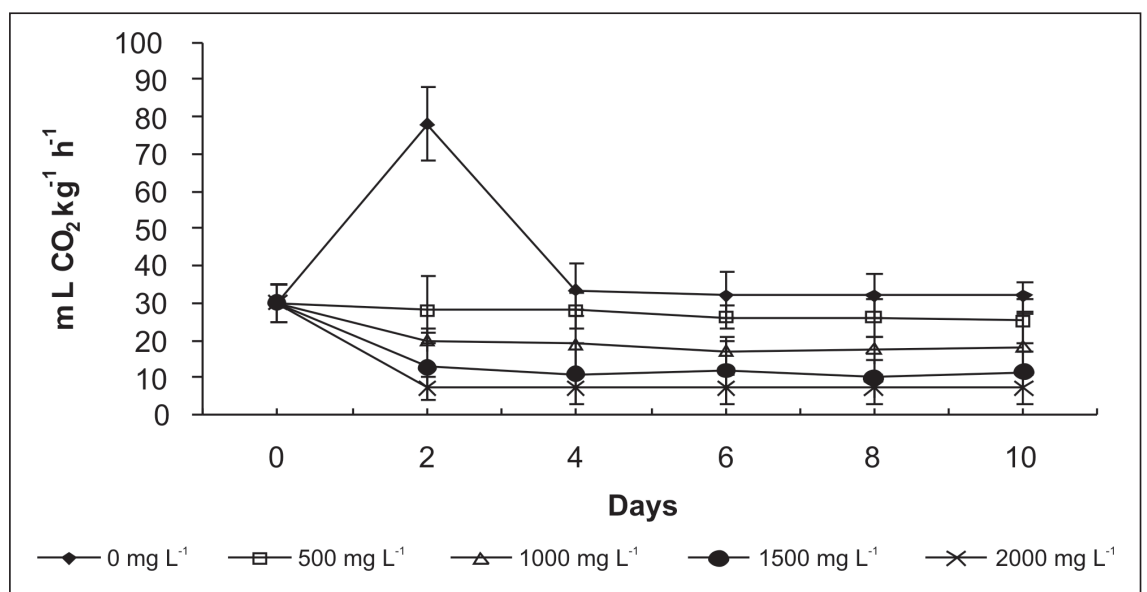

Figure 1. Respiratory activity of fresh-cut beet roots treated with citric acid and stored at $5^{\circ} \mathrm{C}$ for 10 days. Vertical bars represent $\pm \mathrm{SD}$. (atividade respiratória de beterrabas minimamente processadas tratadas com ácido cítrico e armazenadas a $5^{\circ} \mathrm{C}$ por 10 dias. Barras verticais representam o desvio padrão da média). Piracicaba, ESALQ, 2007.

Roots were graded for firmness, color and size.

Roots were peeled inside a cold chamber $\left(10 \pm 1^{\circ} \mathrm{C}\right)$ and immersed in cold water $\left(5 \pm 0,5^{\circ} \mathrm{C}\right)$ for 2 minutes to reduce the abrasion stress. Roots were then shredded ( $2 \mathrm{~mm}$ thick), sanitized for 6 minutes $\left(\mathrm{NaClO} / 200 \mathrm{mg} \mathrm{L}^{-1}\right)$ in order to reduce the risks of microbiological contamination, and rinsed for 1 minute $\left(3 \mathrm{mg} \mathrm{L}^{-1}\right.$ free chlorine) to remove chlorine in excess. The fresh-cut material was centrifuged at 2,200 rpm for 1 minute to remove the water excess.

Fresh-cut beet roots were then treated for 5 minutes with citric acid in the following concentrations: 0 (control, immersion in water), 500; 1,000; 1,500 and $2,000 \mathrm{mg} \mathrm{L}^{-1}$. The material was centrifuged again in the same conditions mentioned above. Minimally processed beet roots were placed in trays and wrapped with PVC plastic film, $14 \mathrm{~mm}$ thick, and stored at $5^{\circ} \mathrm{C}$ and $85-90 \%$ RH for 10 days.

Every two days, the treatments were analyzed for respiratory activity and betacyanin and betaxanthin contents. For the respiratory activity analysis, 180 $\mathrm{g}$ of fresh-cut beet roots were placed in a hermetic sealed jar (0,6 L), which was tightly closed and stored at $5 \mathrm{C}$ for 1 hour. Air samples were taken from the glass jars using a syringe and the respiratory activity was analyzed in $\mathrm{a} \mathrm{CO}_{2}$ analyzer. Betacyanin and betaxanthin were determined according to Kluge et al.
(2006). Two grams of the previous frozen samples were grinded with $5 \mathrm{~mL}$ of distilled water. The homogenate was placed in tublets and centrifuged $(15,000$ rpm) at $4{ }^{\circ} \mathrm{C}$ for 40 minutes. One $\mathrm{mL}$ of the supernatant was added to $24 \mathrm{~mL}$ of distilled water in test tubes. The solution was then homogenized in a Vortex and absorbance was read at 476, 538 and 600 $\mathrm{nm}$.

Calculations were carried out according to the following equations: $x$ $=1,095$ (a-c); $\mathrm{y}=\mathrm{b}-\mathrm{z}-\mathrm{x} / 3.1$; and $\mathrm{z}=\mathrm{a}-$ $\mathrm{x}$, where: $\mathrm{a}=$ absorbance at $538 \mathrm{~nm} ; \mathrm{b}=$ absorbance at $476 \mathrm{~nm}$; $\mathrm{c}=$ absorbance at $600 \mathrm{~nm} ; \mathrm{x}=$ absorbance of betacyanin; $y=$ absorbance of betaxanthin; and $\mathrm{z}=$ absorbance of impurities.

Analyses were performed using a completely randomized design, with 30 treatments arranged in a factorial scheme (five concentrations of citric acid and 6 sampling times), with 5 replications. Data were subjected to analysis of variance and the least significance difference (Fisher L.S.D.) procedure was carried out. Differences between any two treatments larger than the sum of two standard deviations were always significant $(\mathrm{pd}<0.05)$.

\section{RESULTS AND DISCUSSION}

The application of citric acid in different concentrations caused the reduction of $\mathrm{CO}_{2}$ evolution in the fresh- 


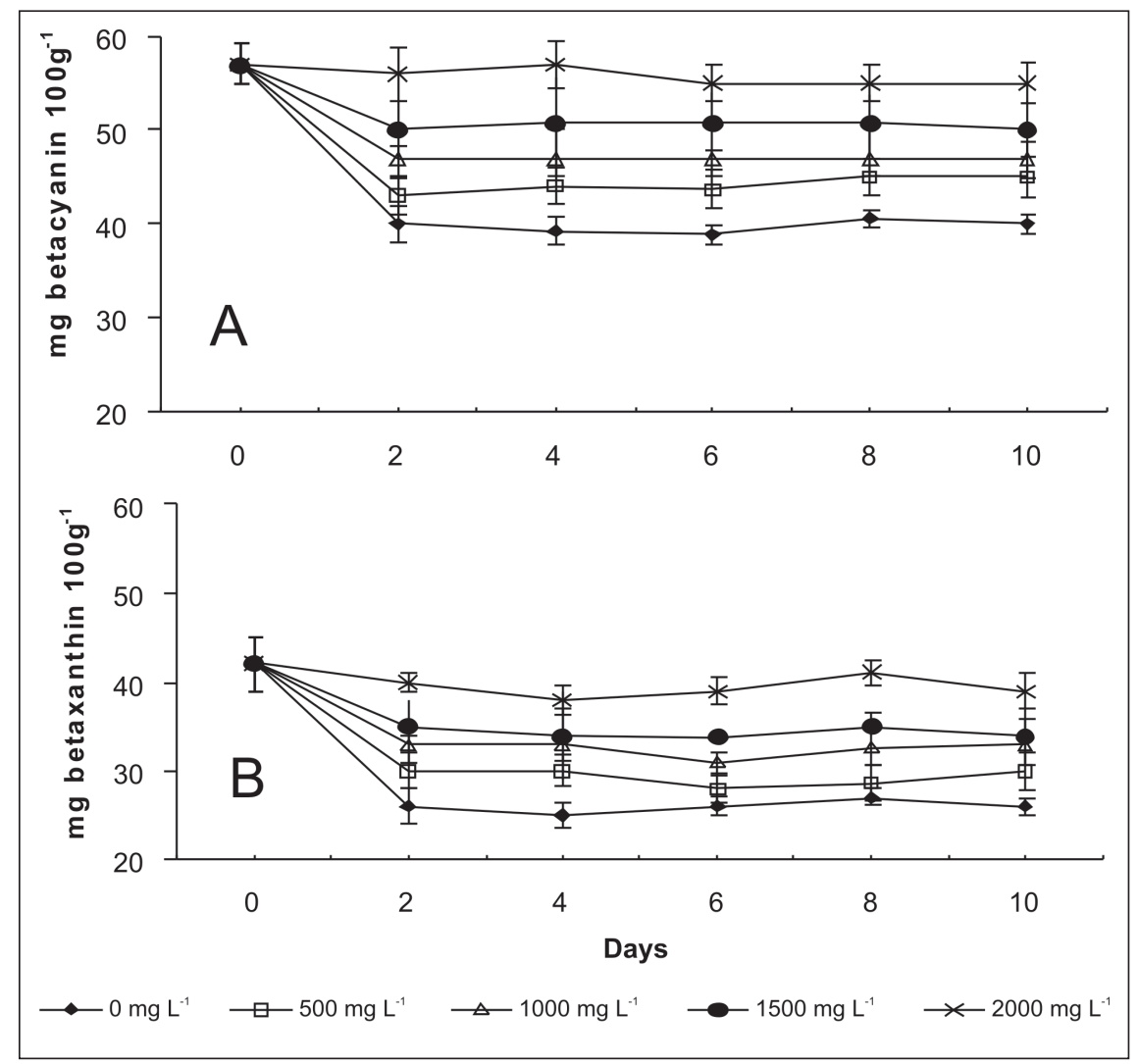

Figure 2. Betacyanin (A) and betaxanthin (B) content of fresh-cut beet roots treated with citric acid and stored at $5^{\circ} \mathrm{C}$ for 10 days. Vertical bars represent \pm SD. (conteúdo de betacianina (A) e betaxantina (B) de beterrabas minimamente processadas tratadas com ácido cítrico e armazenadas a $5^{\circ} \mathrm{C}$ por 10 dias. Barras verticais representam o desvio padrão da média). Piracicaba, ESALQ, 2007.

cut tissue (Figure 1). In the second day of storage, control showed the highest respiratory activity among treatments, reaching around $77 \mathrm{~mL} \mathrm{CO} \mathrm{kg}^{-1} \mathrm{~h}^{-1}$. After the fourth day of storage, carbon dioxide evolution of the untreated tissue stabilized around $30 \mathrm{~mL} \mathrm{CO}_{2} \mathrm{~kg}^{-1} \mathrm{~h}^{-1}$, but remained continuously higher than beet root treated with 1,000 to $2,000 \mathrm{mg}$ $\mathrm{L}^{-1}$ of citric acid (Figure 1).

A citric acid application higher than $500 \mathrm{mg} \mathrm{L}^{-1}$ contributed to a decrease in respiratory activity and no peak in $\mathrm{CO}_{2}$ evolution was observed (Figure 1). After the second day of storage, carbon dioxide evolution stabilized at $25 ; 18$; 10 and $3.5 \mathrm{~mL} \mathrm{CO}_{2} \mathrm{~kg}^{-1} \mathrm{~h}^{-1}$ for 500 , 1,$000 ; 1,500$ and $2,000 \mathrm{mg} \mathrm{L}^{-1}$ of citric acid treatment, respectively.

Results are similar to the findings of Kato-Noguchi \& Watada (1997) who observed that the respiratory activity of fresh-cut carrots was reduced when citric acid concentration was increased. The peak in $\mathrm{CO}_{2}$ evolution verified in the untreated material was probably related to the stress occurred by the time of processing, which caused a disruption in cell tissues, allowing respiratory substrates reaction with their respective enzymes. This kind of result in minimally processed beet root no treated with citric acid was also observed by Vitti et al. (2003). In treated beet roots the stress was reduced as the concentration of citric acid increased. On the other hand, immersion in citric acid solutions caused probably a reduction in the activity of phosphofrutokinase, with subsequent reduction in the synthesis of pyruvic acid in the glycolysis pathway (Kato-Noguchi \& Watada, 1997). The subsequent reduction in the respiratory activity observed in the untreated material after the fourth day was probably related to the self-regulation of the respiratory activity due to the high production of ATP (Purvis,1997).

There were significant differences among treatments during the storage period for the contents of betacyanin, which were around $40 ; 45 ; 48 ; 51$ and $55 \mathrm{mg} 100 \mathrm{~g}^{-1}$ for the fresh-cut material treated with $0 ; 500 ; 1,000 ; 1,500$ and $2,000 \mathrm{mg} \mathrm{L}^{-1}$ of citric acid, respectively (Figure 2A). On the other hand, the levels of betaxanthin in fresh-cut beet roots were around $25 ; 29 ; 33 ; 35$ and 39 $\mathrm{mg} 100 \mathrm{~g}^{-1}$ for the material treated with $0 ; 500 ; 1,000 ; 1,500$ and $2,000 \mathrm{mg} \mathrm{L}^{-1}$ of citric acid, respectively (Figure 2B).

Nilson (1973) observed the content of betacyanin and betaxanthin is cultivar dependent, and the levels of these pigments are around 45 to 210 and 20 to $140 \mathrm{mg} 100 \mathrm{~g}^{-1}$, respectively. Thus, due to the processes of sanitation and rinsing, there is a significant loss of color in the fresh-cut material. The immersion in citric acid solutions or other antioxidant appears to protect the tissue against pigment degradation. As the concentration of the citric acid solution increased, the pigment loss decreased (Figure 2). Salgado (1997) verified that treatments with an antioxidant, such as ascorbic acid, increased the stability of betalain in beet roots. The author suggested that $400 \mathrm{mg} \mathrm{L}^{-1}$ was the best concentration to prevent pigment degradation. The combination of citric and ascorbic acids had no synergistic effect in preventing pigment degradation when compared to the application of one antioxidant alone (Attoe \& Elbe, 1985).

According to our results, it is suggested that the application of citric acid after minimal processing have the ability of reducing carbon dioxide evolution and minimizing the degradation of pigments, which contributes to extend the shelf life of the fresh-cut product.

\section{ACKNOWLEDGEMENTS}

The authors thank to FAPESP (Fundação de Amparo à Pesquisa do estado de São Paulo) for providing financial resource for the execution this experiment (proc. $\mathrm{n}^{\circ} 01 / 00750-2$ ).

\section{REFERENCES}

ATTOE EL; ELBE JHV. 1985. Oxygen involvement betanine degradation: effect of antioxidants. 
Journal of Food Science 50: 106-109.

BEAULIEU JC. 2006. Effect of cutting and storage on acetate and nonacetate esters in convenient, ready-to-eat fresh-cut melons and apples. HortScience 41: 65-73.

BRECHT JK. 1995. Physiology of lightly processed fruits and vegetables. Hortscience 30: 18-22.

CANTWELL MI. 2000. Preparation and quality of fresh-cut produce. In: Encontro Nacional sobre Processamento Mínimo de Frutas e Hortaliças, 2. Proceedings... Viçosa: UFV. p.156-182.

DEGL'INNOCENTI E; GUIDI L, PARDOSSI A, TOGNONI F. 2005. Biochemical study of leaf browning in minimally processed leaves of lettuce (Lactuca sativa L. var. acephala). Journal of Agriculture and Food Chemistry 53: 9980-9984.

GIL MI; AGUAYOE; KADERAA. 2006. Quality changes and nutrient retention in fresh-cut versus whole fruits during storage. Journal of Agriculture and Food Chemistry 54: 42844296.

KATO-NOGUCHI H; WATADAAE. 1997. Citric acid reduces the respiration of fresh-cut carrots.
HortScience 32: 136.

KLUGE RA; COSTA CA; VITTI MCD; ONGARELLI MG; JACOMINO AP; MORETTI CL. 2006. Armazenamento refrigerado de beterraba minimamente processada em diferentes tipos de corte. Ciência Rural 36: 263-270.

MORETTI CL; SARGENT SA. 2000. Alteração de aroma e sabor em frutos de tomate com desordem fisiológica causada por impacto. Scientia Agricola 57: 385-388.

MORETTI CL; SILVA WL; ARAUJO AL. 2000. Quality attributes and carbon dioxide evolution of bell peppers as affected by minimal processing and storage temperature. Proceedings of the Florida State for Horticultural Society 113:156-159.

MORETTI CL; SARGENT SA. 2002. Fresh-cut growth in Brazil. Fresh-cut Magazine 10: 2429.

MORETTI CL; MAROUELLI WA; SILVA WLC. 2002a. Respiratory activity and browning of minimally processed sweet potatoes. Horticultura Brasileira 20: 497-500.

MORETTI CL; BALDWIN E; SARGENT SA; HUBER DJ. 2002b. Internal bruising alters aroma volatile profiles in tomato fruit tissues.
HortScience 37:378-382

NILSON T. 1970. Studies into the pigments in beetroot (Beta vulgaris L. ssp. vulgaris var. rubra L.). Lantbrukhogskolans Annaler 36: 179-219.

NILSON T. 1973. The pigment content in beetroot with regard to cultivar, growth, development and growing conditions. Swedish Journal of Agriculture Research 3: 187-200.

PURVIS AC. 1997. The role of adaptive enzymes in carbohydrates oxidation by stressed and senescing plant tissues. HortScience 321165 1168.

ROJO F; SAABOR A. 2002. Hortifrútis embalados e pré-processados. SuperHiper 28: 8-14.

SALGADO SMA. 1997. Estudo da estabilidade de betalaína extraída da beterraba-vermelha de mesa (Beta vulgaris L.). Viçosa: UFV. 48p. (Tese mestrado).

VITTI MC; KLUGE RA; YAMAMOTTO LK; JACOMINO AP. 2003. Comportamento da beterraba minimamente processada em diferentes espessuras de corte. Horticultura Brasileira 21: 623-626. 